rather than suppressing the arbitrariness of narrative choices, fantasy can breathe new life into its own conventions ${ }^{16}$.

Chapter Six - Women's Coming of Age in Fantasy offers an interesting gender-focused analysis of some fantasy works. Chapter Seven discusses the subgenre of science fantasy, which, according to Attebery, in the hands of a skillful writer, is capable of enhancing both fantastic modes. Finally, Chapter Eight Recapturing the Modern World for the Imagination discusses fantasy works set in mimetic reality and cognitive implications of this literary operation.

Throughout the whole study Attebery proves a talented close reader, supporting his ideas with insightful discussions of a wide range of fantasy texts and often shedding new light on particular plots and characters that have apparently received more than enough attention by other writers. If not for any other reason, the book is definitely worth reading for these interpretations alone.

Due to a wide range of issues undertaken and its cognitive merit Attebery's study is an obligatory reading for all scholars interested in contemporary fantasy literature, regardless of their methodological attitudes or specific interests. As it is written in a friendly and engaging manner, it might be also appreciated by more ambitious fantasy fans who, thanks to it, might better understand their favorite books.

${ }^{16}$ B. Attebery, Strategies..., p. 68.

\title{
Dorota Surdy
}

Uniwersytet Wrocławski

\section{Once Upon a Time...}

DOI: $10.19195 / 0867-7441.22 .17$

Review: Susan Sellers, Myth and Fairy Tale in Contemporary Women's Fiction, Palgrave Macmillan, New York 2001, 210 pp.

Słowa kluczowe: mit, baśń, feministyczna krytyka literacka, współczesna literatura kobieca

Keywords: myth, fairy tale, feminist literary criticism, contemporary women's fiction

Susan Sellers is a British author, translator, editor and novelist ${ }^{1}$. She is Professor of English and Related Literature at the University of St. Andrews and coeditor of the Cambridge University Press edition of Virginia Woolf's works. Her work entitled Myth and Fairy Tale in Contemporary Women's Fiction (2001) is a study concentrating on the way how women write and rewrite myth. The author

${ }^{1} \mathrm{https}: / /$ susansellers.wordpress.com/ (access: 31.07.2016). 
examines selected examples of contemporary women's fiction ${ }^{2}$ through the prism of feminist literary criticism and French feminist theory. Her analysis involves novels and short stories by A.S. Byatt (Dame Antonia Susan Duffy), Christine Crow, Hélène Cixous, Michèle Roberts, Ann Rice, Emma Tennant, Pat Califia, Marina Warner (Dame Marina Sarah Warner), Emma Donoghue, Sheri S. Tepper, Alice Thompson and Angela Carter (Angela Olive Carter-Pearce).

Myth and Fairy Tale in Contemporary Women's Fiction is divided into seven chapters preceded with a short preface which in a clear lucid way tells what this book is about. Sellers explains that she is conscious of limitations of her work. She knows that it could have been written in several times over, with a different set of writers and texts each time. However, the choice of the novels is not accidental and it is not the consequence of ignorance, even if it is questioned by some critics $^{3}$. She had selected them guided by her knowledge, skills and the specificity of the research topic. In spite of the fact that discussed works belong to many different categories, for example science fiction, horror, comedy, all of them are useful for the purpose of her work.

In the opening chapter titled Contexts: Theories of Myth Susan Sellers considers myth's nature and role to examine the issue of feminist rewriting. She refers to numerous definitions of myth proposed, for example, by Sigmund Freud, Jean-François Lyotard, Robert Graves (Robert von Ranke Graves), Mircea Eliade, T.S. Eliot (Thomas Stearns Eliot), Marina Warner, James George Frazer, Raffaele Pettazzoni, Jessie Laidley Weston, Bronisław Malinowski, Joseph Campbell, Carl Jung, Roland Gèrard Barthes and Claude Lévi-Strauss. As a result, she achieves a multifaceted presentation of the term which without any doubt may be useful as an introduction for the study of myth. However, the author insistence on presenting a lot of different approaches turns chapter into a series of one-sentence summaries of various theories. It makes Sellers's work somewhat obscure. Reading it can be quite difficult and tiring for the reader. Next, she describes in the same way fairy tales, folk tales and wonder tales. Sellers presents a list of how different people have defined discussed terms, but she does not give her own opinion. She only stresses that works of Bruno Bettelheim, Jack Davies Zipes and Marina Warner particularly influenced her point of view. That is all. This lack of the author's own opinion seems to be the biggest drawback of the book.

Undoubtedly, Sellers presents the wide variety of interesting definitions of myth and fairy tale, however it is not easy to go through something what looks like

2 S. Robinson, What's Contemporary about Contemporary Women's Fiction?, "MFS Modern Fiction Studies" 2001, No. 4 (47), p. 986-994.

${ }^{3}$ She is criticized, for example, by Charlene Ball who claims that Sellers is working only within the limits of white late $20^{\text {th }}$ century U.S. and British women writers in English, using U.S. and European feminist theory and ignoring nonwhite authors and mythic traditions. M.Ch. Ball, Myth and Fairy Tale in Contemporary Women's Fiction, and: Tracing Arachne's Web: Myth and Feminist Fiction (review), "NWSA Journal” 2004, No. 2, pp. 229-233. 
a very useful and comprehensive but not discovering anything new report. Moreover, rich and professional, but in the same moment demanding and sometimes not lucid scientific language and never-ending citation notes located at the end of the book make reception even more difficult.

In six following chapters Sellers considers whether feminist rewriting of myth and fairy tale is possible and analyses the examples of contemporary women's fiction. She begins with the motifs of beauty and monstrosity drawing comparison between Byatt's The Djinn in the Nightingale's Eye and Fay Weldon's The Life and Loves of a She Devil and ends with a fascinating description of Carter's Mirrors and Mothers. Sellers does not describe books in isolation. She presents interesting parallels. For example, an analysis of Crow's Miss X or the Wolf Woman is carried out next to Cixous's The Book of Promethea. The author reads The Book of Mrs Noah and Impossible Saints by Roberts in terms of the theoretical works of Luce Irigaray. Moreover, she discusses the vampires' prose of Rice together with Tennant's Two Women of London: The Strange Case of Ms Jekyll and Mrs Hyde. These retellings of famous literary works are read in the context of Julia Kristeva's Powers of Horror. Next, works by Warner, Donoghue, Tepper and Thompson are read in connection with Judith Butler's concept of performativity. All mentioned above analyses are carried out in a professional, interesting way. Undoubtedly, the author has a big knowledge about presenting works. Myth and Fairy Tale in Contemporary Women's Fiction ends with a well written conclusion. Unfortunately, the promising ending finishes very fast and leaves the reader with a sense of dissatisfaction.

Susan Sellers uses forms we and us. It means, that she identifies herself with the readers and tries to analyse the power of myth from the point of view of a member of the community. She believes that myth works as a filter for personal experiences and shapes the way of understanding them. Mythography not only influences people and their mindscape, but also has a significant impact on contemporary feminist fiction. According to Sellers, rewriting stories and creating new myth's models could initiate individual and social changes and change the situation of the woman who in Western patriarchal culture exists only in relation to man.

Summing up, Sellers's book is a result of hard academic work. The scope of the author's interests and her scholarly ambitions certainly deserve respect. She is very knowledgeable about the topic, familiar with the Greco-Roman mythic tradition, European fairy tales, feminist literary criticism, French feminist theory, the history of research on myth and fairy tales. Undoubtedly, Myth and Fairy Tale in Contemporary Women's Fiction can be highly recommended for all researchers of myth. 